\title{
Mating type and sexual fruiting body of Botrytis elliptica, the causal agent of fire blight in lily
}

\author{
Razak Bin Terhem • Martijn Staats • \\ Jan A. L. van Kan
}

Accepted: 6 March 2015 / Published online: 28 March 2015

(C) The Author(s) 2015. This article is published with open access at Springerlink.com

\begin{abstract}
Botrytis elliptica is a necrotrophic pathogen that specifically infects Lilium species. Previous records show that $B$. elliptica collected in the field can successfully develop apothecia in vitro, however, there are no formal descriptions of apothecia of B. elliptica. The aim of this study was to analyse the sequence of the mating type loci of $B$. elliptica and produce apothecia in the laboratory in order to describe their morphology. The sequences of both MAT alleles (MAT1-1 or MAT1-2) of $B$. elliptica were determined and compared to the sister taxa, Botrytis cinerea and Sclerotinia sclerotiorum. Two strains of each mating type were used in crosses under controlled conditions to produce apothecia. Primordium
\end{abstract}

Electronic supplementary material The online version of this article (doi:10.1007/s10658-015-0639-2) contains supplementary material, which is available to authorized users.

R. B. Terhem · J. A. L. van Kan $(\bowtie)$

Laboratory of Phytopathology, Wageningen University,

Droevendaalsesteeg 1, 6708 PB Wageningen,

The Netherlands

e-mail: jan.vankan@wur.nl

\section{R. B. Terhem}

Department of Forest Management, Faculty of Forestry, Universiti Putra Malaysia, 43400 Serdang, Malaysia

\section{Staats}

Biosystematics Group, Wageningen University, Droevendaalsesteeg 1, 6708 PB Wageningen,

The Netherlands

Present Address:

M. Staats

RIKILT Wageningen UR, P.O. Box 230, 6700

AE Wageningen, The Netherlands rupture from sclerotial tissue occurred 74 days after fertilization and a mature apothecium formed within 1 month after rupture. The apothecia are 7 to $12 \mathrm{~mm}$ in height with a disk of 3 to $4 \mathrm{~mm}$ in diameter and 0.5 to $1 \mathrm{~mm}$ in thickness. The apothecial disk is usually umbilicate, depressed to funnel and rounded in shape. The number of apothecia growing on a sclerotium was one to nine. Asci are long, cylindrical with a size of $208 \times$ $14 \mu \mathrm{m}$, thin walled and bearing eight ascospores. Ascospores are hyaline in colour, ellipsoidal with rounded ends, usually 18 to $24 \mu \mathrm{m}$ in length and 6 to $10 \mu \mathrm{m}$ in width (mean $19.5 \times 8 \mu \mathrm{m}$ ). Ascospores were infectious on lily leaves.

Keywords Apothecia - Lily fire blight · Mating type · Sexual reproduction

\section{Introduction}

There are various modern lily cultivars on the market which originate from the genus Lilium of the family Liliaceae. The genus Lilium comprises about 100 species and was classified into seven sections, of which three comprise important hybrid cultivars for breeding: Asiatic, Oriental and Longiflorum (MacRae 1998; Shahin et al. 2012). Lilies are the second largest flower bulb crop in the Netherlands, and the largest flower bulb product in the world (Kamenetsky and Okubo 2012). Fire blight, also known as leaf blight is a major threat to lily production worldwide. The disease poses a major economic threat and has been recorded in Argentina, 
China, Korea, Italy, Japan, Netherlands, Taiwan, United Kingdom, and the United States (Bastiaansen et al. 1997; Chiou and Wu 2001; Doss et al. 1988; Furukawa et al. 2005; Hwang 2001; Mansfield and Hutson 1980; Migheli et al. 1990). During the growing season, fire blight may affect numerous lily species such as Lilium candidum, Lilium longiflorum, Lilium auratum, and Lilium speciosum (Bastiaansen et al. 1997; Doss et al. 1988; Fang Hsieh et al. 2001; Furukawa et al. 2005). The disease is caused by Botrytis elliptica (Berk) Cooke, a necrotrophic pathogen that only infects lilies. Host specificity of $B$. elliptica was proposed to be caused by the production of an as yet unidentified, secreted necrosis-inducing protein that causes programmed cell death (Van Baarlen et al. 2004) and therefore presumably serves as a host-specific necrotrophic effector (Vleeshouwers and Oliver 2014). Symptoms such as necrotic spots on leaves and petals are the early signs of infection. The necrotic lesions develop and expand quickly under favourable environmental conditions (Chiou and Wu 2001; Hwang 2001; van Baarlen et al. 2004). Control measures using fungicides for $B$. elliptica are common practice worldwide, however, it has been reported that $B$. elliptica acquires resistance to several fungicides including benzimidazoles, dicarboximides, diethofencarb, and two sterol biosynthesis inhibitors (Chastagner and Riley 1990; Migheli et al. 1990).

Fruiting bodies of species in the genus Botrytis, called apothecia, are rarely found in the field. Apothecia are ascomas with an open cup shape, on top of a stipe, and brown in colour (Whetzel 1945). Apothecia develop from sclerotia and act as a platform to discharge ascospores from the asci (Pöggeler et al. 2006). Apothecia of the genus Botrytis vary in size depending on the species, ranging from 2 to $25 \mathrm{~mm}$ in height and 1 to $6 \mathrm{~mm}$ in diameter of the apothecial disk. Several studies have shown that sclerotia must be fertilized with microconidia in order to develop apothecia (Beever and Parkes 1993; Faretra and Antonacci 1987; Fukumori et al. 2004; Groves and Loveland 1953). Mature Botrytis apothecia can normally be observed 2 months after fertilization (Faretra and Antonacci 1987; Hennebert 1973; Terhem and van Kan 2014).

Most members of the genus Botrytis are typically designated as having heterothallic mating systems. However, some species in the genus are reported to have homothallic reproductive mating systems, for example Botrytis porri and Botrytis globosa (Buchwald 1953;
Elliott 1964). B. elliptica is believed to have a heterothallic mating system, requiring a cross between different alleles to undergo sexual development and form apothecia (van den Ende and Pennock-Vos 1996). The mating type locus in the genus Botrytis is designated as $M A T$, with two alleles defined as MAT1-1 and MAT1-2. As is common in ascomycetes, the MAT alleles lack sequence similarity but are flanked by identical genes, i.e., APN2 and SLA2 (Pöggeler et al. 2006). The presence of both $M A T$ alleles will activate sexual development. Two decades ago, efforts were made to generate apothecia from $B$. elliptica, but complete apothecia failed to form. The apothecia failed to expand the apothecial disk which resulted in empty asci and ascospores (Chastagner et al. 1992). Some years later, van den Ende and Pennock-Vos (1996) managed to collect apothecia in a lily production field in Lisse, the Netherlands and successfully performed crosses with $B$. elliptica strains, but a formal description of the apothecia of $B$. elliptica was not provided. Staats et al. (2007) could not detect apothecia of B. elliptica during a field survey; however, they performed AFLP analysis to study the genetic diversity in the population. Over $60 \%$ of haplotypes of $B$. elliptica were unique to a single isolate and only $2 \%$ of all pairwise haplotype comparisons differed by less than four markers. Furthermore, haplotypes that were prominent in one growing season were not found again in the next year. These data collectively provided strong evidence for the occurrence of sexual reproduction in the field (Staats et al. 2007). Also field surveys in North America and Taiwan failed to reveal the presence of apothecia of B. elliptica in the field (Huang et al. 2001). Currently, there is no documentation or description of apothecia of B. elliptica available to the public. The aim of this study was to analyse the sequence of the MAT loci of B. elliptica and to produce apothecia in the laboratory in order to describe their morphology.

\section{Materials and methods}

\section{Strains}

Six B. elliptica strains (Be9601, Be9605, Be9610, Be9612, Be9623, Be0004) collected in a lily production field in Lisse, the Netherlands in the years 1996 and 2000, were provided by dr. J. van Doorn (PPO Lisse). Strains were plated on malt extract agar (MEA) and 
incubated at $20^{\circ} \mathrm{C}$ with continuous exposure to nearUV light and white light until cultures sporulated.

\section{B. elliptica genome sequence}

Genomic DNA was isolated from strain Be9601 using a Gentra Puregene DNA purification kit (Qiagen, Venlo, the Netherlands), and used for whole genome sequencing by DNAvision in Liège, Belgium. The library containing inserts with an average length of 157 bp was sequenced on an Illumina Hiseq2000 platform by paired-end sequencing with a read length of $100 \mathrm{bp}$. A total of 33.2 million reads (yielding a dataset of $>5 \mathrm{~Gb}$ ) were assembled using Velvet 1.2.05 (Zerbino and Birney 2008) with a k-mer value of 43 . The Be9601 assembly consisted of 7,860 contigs $(N 50=32,840)$ and had a total length of $47.6 \mathrm{Mbp}$.

Identification of mating type alleles

Freeze-dried mycelium was used for genomic DNA extraction using a Gentra Puregene DNA purification kit (Qiagen). The entire MAT locus could be amplified from strains with either of the MAT alleles, using primers annealing in the regions flanking the locus: BOTMAT5 (GTGACTGTAAAACGACGGCCAGTTCCGTATTC ACAATCCATCC) and BOTMAT3 (GTGACCAGGA AACAGCTATGACCACATACTCGCATTAGTGGA AC). PCR performed on 10-50 ng DNA with Expand polymerase (Roche) and primer pair BOTMAT5/ BOTMAT3 in a $25 \mu \mathrm{l}$ reaction volume yielded a fragment of $\sim 4.3 \mathrm{~kb}$. Amplification conditions were: $95^{\circ} \mathrm{C}$ $5 \mathrm{~min}$, then 30 cycles of $94{ }^{\circ} \mathrm{C}$ for $30 \mathrm{~s}, 55^{\circ} \mathrm{C}$ for $30 \mathrm{~s}$ and $72{ }^{\circ} \mathrm{C}$ for $5 \mathrm{~min}$, followed with a final extension of $72{ }^{\circ} \mathrm{C}$ for $7 \mathrm{~min}$. The amplicon from B.elliptica strain Be9623 was cloned in a TOPO-XL PCR plasmid (Life Technologies) and entirely sequenced by Baseclear (Leiden, The Netherlands) using a primer walking strategy.

To identify the MAT alleles of strains or single ascospore progeny cultures by PCR, primer pairs were used that are specific for either of the alleles: MAT1-1 F (TGGTGTAAAAAGATTCCGTATCCG) and MAT11R (CACCATATGCATTCTGAGTGGAAG); or MAT1-2 F (ATCACGGCACTGTCCTCGAAAC) and MAT1-2R (GAAGAGGTTCCAGACACAGATTG).

PCRs were performed with GoTaq polymerase (Promega, Leiden, The Netherlands), according to the manufacturer's instructions. Amplification conditions were: $95{ }^{\circ} \mathrm{C} 5 \mathrm{~min}$, then 35 cycles of $94{ }^{\circ} \mathrm{C}$ for $30 \mathrm{~s}$, $52{ }^{\circ} \mathrm{C}$ for $30 \mathrm{~s}$ and $72{ }^{\circ} \mathrm{C}$ for $2 \mathrm{~min}$, followed with a final extension of $72{ }^{\circ} \mathrm{C}$ for $5 \mathrm{~min}$.

\section{Sexual crosses}

To obtain sclerotia, strains were plated on MEA and incubated in complete darkness at $15{ }^{\circ} \mathrm{C}$ for 4 weeks, followed by incubation at $0{ }^{\circ} \mathrm{C}$ for 4 weeks. Sexual crosses were set up in a reciprocal way using a standard protocol for crosses in B. cinerea (Faretra et al. 1988; van der Vlugt-Bergmans et al. 1993). In total, 24 sclerotia were used in one microtiter plate of six wells. Every well contained four sclerotia (maternal parent) that were fertilized with $3 \mathrm{ml}$ of microconidia (paternal parent) of the mating partner. The microtiter plate was then sealed and incubated at $12{ }^{\circ} \mathrm{C}$ under neon light with a 12 -h photoperiod. Non-spermatized sclerotia in sterile MilliQ water were used as a negative control. All crosses were set up with two strains of opposite mating types.

Sampling of ascospores and production of single ascospore progeny

To obtain ascospores, an apothecium was gently grinded with a mortar and pestle, followed by the addition of sterile MilliQ water, and mixed. The homogenate containing complete asci, ascospores and hymenium debris was filtered over glasswool fibre in a $5 \mathrm{ml}$ pipette tip. The flowthrough contained predominantly ascospores, with little contamination by asci and hymenium tissue. Ascospores were counted using a haemocytometer. To obtain single ascospore progeny cultures, ascospores were plated on MEA at low density, up to 30 ascospores per plate, and incubated at $20{ }^{\circ} \mathrm{C}$. After 2 days of incubation, germlings emerging from single ascospores were transferred to fresh MEA plates. At least 15 single ascospore cultures were collected from each individual apothecium. Genomic DNA was extracted from single ascospore cultures after 4 days of growth on MEA. PCR was performed as described above to identify their MAT allele. A chi-square test for the segregation of MAT alleles in the progeny was performed with a confidence level $P=0.05$.

\section{Light microscopy}

Transverse sections of apothecia were mounted on a slide with filter-sterile MilliQ water. Observations were made with a Nikon Eclipse 90i (Nikon Instruments, 
Badhoevedorp, the Netherlands) compound microscope attached with a Nikon DS-5MC camera. Measurements were performed using N.I.S-Elements AR 2.30 software (Nikon Instruments, Badhoevedorp, the Netherlands). At least 40 ascospores, asci, hymenia, pharaphyses, ectal excipulum, and medullary excipulum were measured. The mean, standard deviation, and $95 \%$ confidence intervals were calculated.

Infection assay

Ascospores were collected from a mixture of 10 apothecia using the method described above. The ascospore suspension was adjusted to $1 \times 10^{6} \mathrm{ml}^{-1}$ in potato dextrose broth (12 g/l). 6-12 droplets of $3 \mu \mathrm{l}$ of ascospore suspension were inoculated on the lower sides of lily leaves freshly cut from mature plants. Inoculated leaves were stored in a box with high relative humidity, $>95 \%$, and placed at room temperature. The infection assay was performed with 3-5 leaves per treatment and was repeated three times.

\section{Results}

The mating type locus of Botrytis elliptica

As in most ascomycetes, the mating type (MAT) locus in Sclerotiniaceae is flanked by two highly conserved genes, APN2 (a homologue of the Saccharomyces cerevisiae $A P N 2$ gene encoding a DNA lyase) and SLA2 (a homologue of the $S$. cerevisiae SLA2 gene encoding a cytoskeleton assembly protein) (Amselem et al. 2011). The draft genome sequence of B. elliptica isolate Be9601 was determined (van Kan and Staats, unpublished). Nucleotide alignment was performed to identify the region that is homologous to the MAT locus of $B$. cinerea (Amselem et al. 2011). The MAT locus of Be9601 (Fig. 1) appeared to contain the MAT1-1 allele, which includes the MAT1-1-1 gene (encoding the MATalpha domain) and the MAT1-1-5 gene, in the same configuration as in B. cinerea strain B05.10 (Amselem et al. 2011). Using primers BOTMAT5 and BOTMAT3 on DNA of B.elliptica Be9623, a fragment was amplified that contains the MAT1-2 allele, which includes the MAT1-2-1 gene (encoding a high mobility group domain protein) and the MAT1-2-4 gene (Fig. 1), in the same configuration as in $B$. cinerea strain T4 (Amselem et al. 2011). The four MAT genes in B. elliptica were $>90 \%$ similar to their orthologs in B. cinerea and $>75 \%$ similar to their orthologs in Sclerotinia sclerotiorum (Table 1; Supplemental Figure 1). Alike in the MAT loci in $B$. cinerea, there was a truncated fragment of the MAT1-2-1 gene in the MAT1-1 locus and a truncated fragment of the MAT1-1-1 gene in the MAT1-2 locus (Fig. 1). Both gene fragments lack start codons as well as their typical DNA-binding domain and thus appear non-functional. The sequences of both MAT alleles were deposited in Genbank under accession numbers KM219113 (MAT1-1) and KM243314 (MAT1-2).
Fig. 1 Structure of the MAT locus in B.elliptica. Top panel: MAT1-1 allele of strain Be9601; bottom panel: MAT1-2 allele of strain Be9623. MAT alleles are nonhomologous in DNA sequence, but are flanked by identical genes, $A P N 2$ and SLA2. Introns in the MAT genes are indicated by lines connecting the exons (indicated by boxes). The boxes marked with dotted circles represent truncated fragments of the MAT1-2-1 gene (in the MAT1-1 locus in the top panel) and the MAT1-1-1 gene (in the MAT1-2 locus in the bottom panel), respectively. The direction of transcription is indicated by arrows

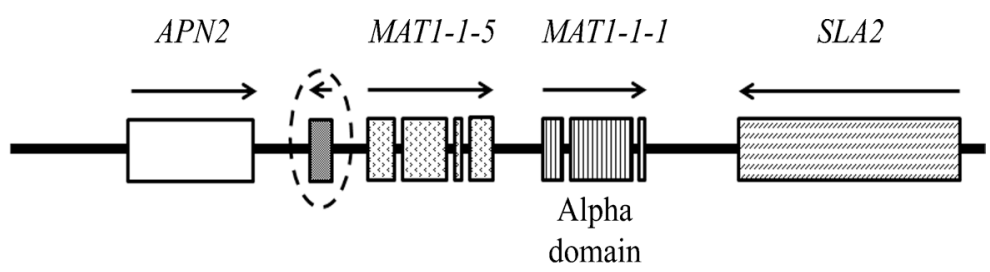

Botrytis elliptica MAT1-1

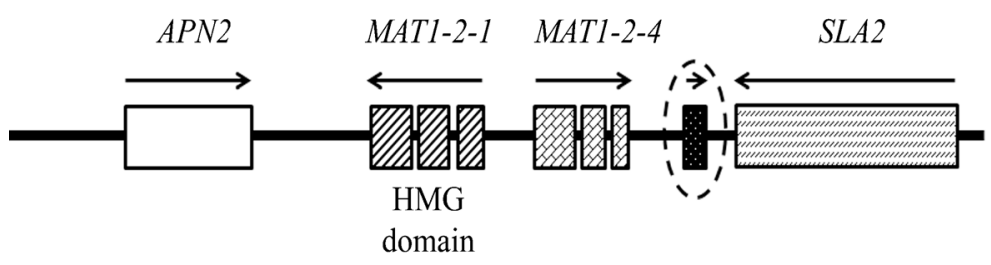

Botrytis elliptica MAT1-2 
Table 1 Homology of B. elliptica MAT genes to orthologs in other Sclerotiniaceae

\begin{tabular}{lllllll}
\hline B. elliptica gene & $\begin{array}{l}\text { Protein length } \\
\text { (amino acid residues) }\end{array}$ & \multicolumn{2}{l}{$\begin{array}{l}\text { Homology to B.cinerea } \\
\text { ortholog }\end{array}$} & & \multicolumn{2}{l}{$\begin{array}{l}\text { Homology to } \\
\text { S.sclerotiorum ortholog }\end{array}$} \\
& & Identity & Similarity & & Identity & Similarity \\
\hline MAT1-1-1 & 353 & 96 & 97 & & 81 & 84 \\
MAT1-1-5 & 376 & 86 & 92 & & 75 & 87 \\
MAT1-2-1 & 376 & 94 & 96 & & 78 & 86 \\
MAT1-2-4 & 279 & 82 & 90 & & 63 & 76 \\
\hline
\end{tabular}

\section{Characterization of strains}

Four different $B$. elliptica strains were analyzed by PCR for their MAT allele. Two strains carried the MAT1-1 allele and another two strains carried the MAT1-2 allele. To analyse the production of sclerotia, these strains were plated on MEA plates and incubated in a $15{ }^{\circ} \mathrm{C}$ incubator in darkness. All strains formed sclerotia, except for Be9610 (MAT1-1). Approximately 30 sclerotia were produced in one plate. Fully developed sclerotia were observed in the MEA plate after 30 days. Table 2 shows the characterization of strains.

\section{Sexual crosses}

To analyse the ability of $B$. elliptica to develop apothecia, the MAT1-1 strains were crossed with the MAT1-2 strains in all possible combinations. Because of the failure of Be9610 to produce sclerotia, this strain could only be used as paternal parent (microconidia). Of the nine crosses that were set up, four crosses were fertile and resulted in the formation of apothecia. The crosses that produced apothecia were all set up from MAT1-2 strains as the maternal parent (sclerotia). No apothecia formed from crosses that used MAT1-1 strain Be9612 as the maternal parent. As a control, sclerotia from the MAT1-1 strain or the MAT1-2 strain that were incubated in sterile MilliQ water did not produce apothecia. Table 3 displays the results of the sexual crosses. The experiment was performed three times with identical results.

Apothecia were sampled from two different fertile crosses, and at least 15 single ascospore progeny were cultured from three independent apothecia of each. To identify the MAT alleles in the progeny, amplification of genomic DNA was performed by PCR with $M A T$-allelespecific primers. Table 4 shows that the MAT alleles segregated almost $1: 1$ in progeny. In one of the three experiments, the segregation was skewed, with the MAT1-1 allele being dominant for reasons that remain unexplained. A chi-square test indicated that, over the entire set of three biological repeats, the segregation ratio between the MAT alleles did not significantly deviate from 1:1 $(P<0.05$, Table 4).

Morphological description of sclerotia and apothecia

Morphological structures of apothecia of $B$. elliptica were described based on the general descriptions by Whetzel (1945). Sclerotia are plano-convex, black, with irregular shape, and sometimes firmly attached to each other. Sclerotia range in size from 3 to $14 \mathrm{~mm}$, and are frequently concave or hollow on the inward. Optimal conditions for development of sclerotia are in malt extract agar in darkness, in a temperature range between $15^{\circ} \mathrm{C}$ and $20^{\circ} \mathrm{C}$.

From 74 days after fertilization onwards, primordia ruptured from the surface of sclerotia and sometimes from the bottom (Fig. 2a). The primordia develop into a stipe in 7 to 10 days after emergence. The stipe is cylindrical and erected (Fig. 2b, c). The stipe surface is pubescent, scabrous, light brown in colour, 7 to $12 \mathrm{~mm}$ in height, and 1.5 to $2 \mathrm{~mm}$ in width. One to nine (mean= four) apothecia emerged on a sclerotium. The apothecial

Table 2 Morphological and molecular characterization of B. elliptica strains

\begin{tabular}{lllll}
\hline Strain & Microconidia & Macroconidia & Sclerotia & $\begin{array}{l}\text { Mating } \\
\text { type allele }\end{array}$ \\
\hline Be9610 & Yes & Yes & No & $M A T 1-1$ \\
Be9612 & Yes & Yes & Yes & $M A T 1-1$ \\
Be9605 & Yes & Yes & Yes & $M A T 1-2$ \\
Be0004 & Yes & Yes & Yes & $M A T 1-2$ \\
\hline
\end{tabular}


Table 3 Results of sexual crosses

\begin{tabular}{|c|c|c|c|c|c|c|}
\hline \multirow{8}{*}{ Table 3 Results of sexual crosses } & Cross & Sclerotia & Microconidia & Replicates $^{\mathrm{a}}$ & \# Repeats ${ }^{\mathrm{b}}$ & Apothecia \\
\hline & 1 & Be9612 & $\mathrm{Be} 0004$ & 3 & 3 & - \\
\hline & 2 & $\mathrm{Be} 0004$ & Be9612 & 3 & 3 & + \\
\hline & 3 & Be9612 & Be9605 & 3 & 3 & - \\
\hline & 4 & Be9605 & Be9612 & 3 & 3 & + \\
\hline & 5 & $\mathrm{Be} 0004$ & Be9610 & 3 & 3 & + \\
\hline & 6 & Be9605 & Be9610 & 3 & 3 & + \\
\hline & 7 & Be9612 & Sterile MilliQ water & 3 & 3 & - \\
\hline${ }^{\mathrm{a}}$ number of biological replicates & 8 & $\mathrm{Be} 0004$ & Sterile MilliQ Water & 3 & 3 & - \\
\hline $\begin{array}{l}\text { Within an experiment } \\
{ }^{b} \text { number of repeated experiments }\end{array}$ & 9 & Be9605 & Sterile MilliQ Water & 3 & 3 & - \\
\hline
\end{tabular}

disk is umbilicate, depressed to funnel and round in shape, usually 3 to $4 \mathrm{~mm}$ in diameter and 0.5 to $1 \mathrm{~mm}$ thick. It is slightly shallow, cup-shaped and becomes flat when mature; light brown in colour, becoming dark brown at maturity (Fig. 2d, e). Apothecia are mature 94 to 104 days after fertilization. At first the margin of the disk is entire, becoming serrate to irregular (not shown). Asci formed in the apothecial disk were long and cylindrical in shape with an average dimension of $200 \times 14 \mu \mathrm{m}(n=40)$ (Fig. 2f). An apical pore was not clearly observed in the ascus tip. The ascus has a thin wall and bears eight ascospores (Fig. 2f). The ascospores are hyaline, ellipsoidal with rounded ends, usually 18.5 to $24 \mu \mathrm{m}$ in length (mean $19.5 \pm 1.3 \mu \mathrm{m}, n=40$ ) and 6 to $10 \mu \mathrm{m}$ in width $(8.1 \pm 0.8 \mu \mathrm{m}, n=40)$ (Fig. $2 \mathrm{~g}$ ). The medullary excipulum ranges in shape between textura globosa and textura angularis, with a thickness 240 to $344 \mu \mathrm{m}(n=40)$ (Fig. $2 \mathrm{~h})$. The underside of the apothecial disk is pubescent. Ectal excipulum is in the shape of textura globosa with a thickness of 59 to $87 \mu \mathrm{m}$ $(n=40)$ (Fig. 2i). The hymenium ranges from 87 to $106 \mu \mathrm{m}$ in height $(n=40)$ and the subhymenium from 100 to $124 \mu \mathrm{m}(n=40)$. The size of paraphyses ranges from $197 \mu \mathrm{m}$ to $291 \mu \mathrm{m}(n=40)$.

Infectivity of ascospores

Droplets of ascospore suspensions were inoculated on the lower side of lily leaf surfaces. As a control, suspensions of asexual conidia were inoculated at the same density. Symptom development became visible at 20 $24 \mathrm{~h}$ post inoculation (hpi) and was indistinguishable between the ascospores and conidia (not shown). The infected area turned brown in colour and necrotic spots developed at the infection site. At 24 hpi, the lesion was approximately $1 \mathrm{~mm}$ in diameter, equivalent to the size

Table 4 Segregation of MAT alleles in the progeny

\begin{tabular}{|c|c|c|c|c|c|c|c|}
\hline \multirow[t]{2}{*}{ Cross } & \multirow[t]{2}{*}{ Sclerotia } & \multirow[t]{2}{*}{ Microconidia } & \multirow{2}{*}{$\begin{array}{l}\text { Apothecium } \\
\text { (biological replicates) }\end{array}$} & \multicolumn{2}{|c|}{ Mating types } & \multirow{2}{*}{$\begin{array}{l}\text { Total no. } \\
\text { of ascospores }\end{array}$} & \multirow{2}{*}{$\begin{array}{l}\text { Chi square } \\
\text { value }\end{array}$} \\
\hline & & & & MAT1-1 & MAT1-2 & & \\
\hline \multirow[t]{4}{*}{1} & \multirow[t]{4}{*}{ Be0004 } & \multirow[t]{4}{*}{ Be9612 } & 1 & 11 & 13 & 24 & $0.09^{*}$ \\
\hline & & & 2 & 7 & 8 & 15 & $0.02^{*}$ \\
\hline & & & 3 & 18 & 2 & 20 & 5.28 \\
\hline & & & Total & 36 & 23 & 59 & $2.86^{*}$ \\
\hline \multirow[t]{4}{*}{2} & \multirow[t]{4}{*}{ Be9605 } & \multirow[t]{4}{*}{ Be9612 } & 1 & 11 & 10 & 21 & $0.02^{*}$ \\
\hline & & & 2 & 7 & 9 & 16 & $0.09^{*}$ \\
\hline & & & 3 & 16 & 2 & 18 & 4.45 \\
\hline & & & Total & 34 & 31 & 55 & $3.07^{*}$ \\
\hline
\end{tabular}

* no significant deviation from 1:1 segregation in the progeny $(P<0.05)$ 
of the inoculation droplet. Hyphae were growing on the infected area and could be examined under the light microscope. The lesions expanded to $2-4 \mathrm{~mm}$ in diameter at $36 \mathrm{hpi}$ and lesions were circular to oval in shape (Fig. 3). At 48 hpi, the first botryose clusters of spores could be observed in some infected areas. At 4 weeks post inoculation, sclerotia formed on lily leaves and had a typical appearance of B. elliptica sclerotia (not shown)

\section{Discussion}

In this study we confirmed that B. elliptica has a heterothallic mating system with two alleles: MAT1-1 and MAT1-2. Apothecia of B. elliptica can be produced in the laboratory after sexual crosses of two strains of opposite mating types, using a standard protocol developed for B. cinerea (Faretra et al. 1988; van der VlugtBergmans et al. 1993) although B. elliptica apothecia
Fig. 2 Morphology of sexual structures of $B$. elliptica. a,b primordia, c stipe, $\mathbf{d}, \mathbf{e}$ mature apothecia, $\mathbf{f}$ ascospores in asci, $\mathbf{g}$ ascospores, $\mathbf{h}$ medullary excipulum, i ectal excipulum

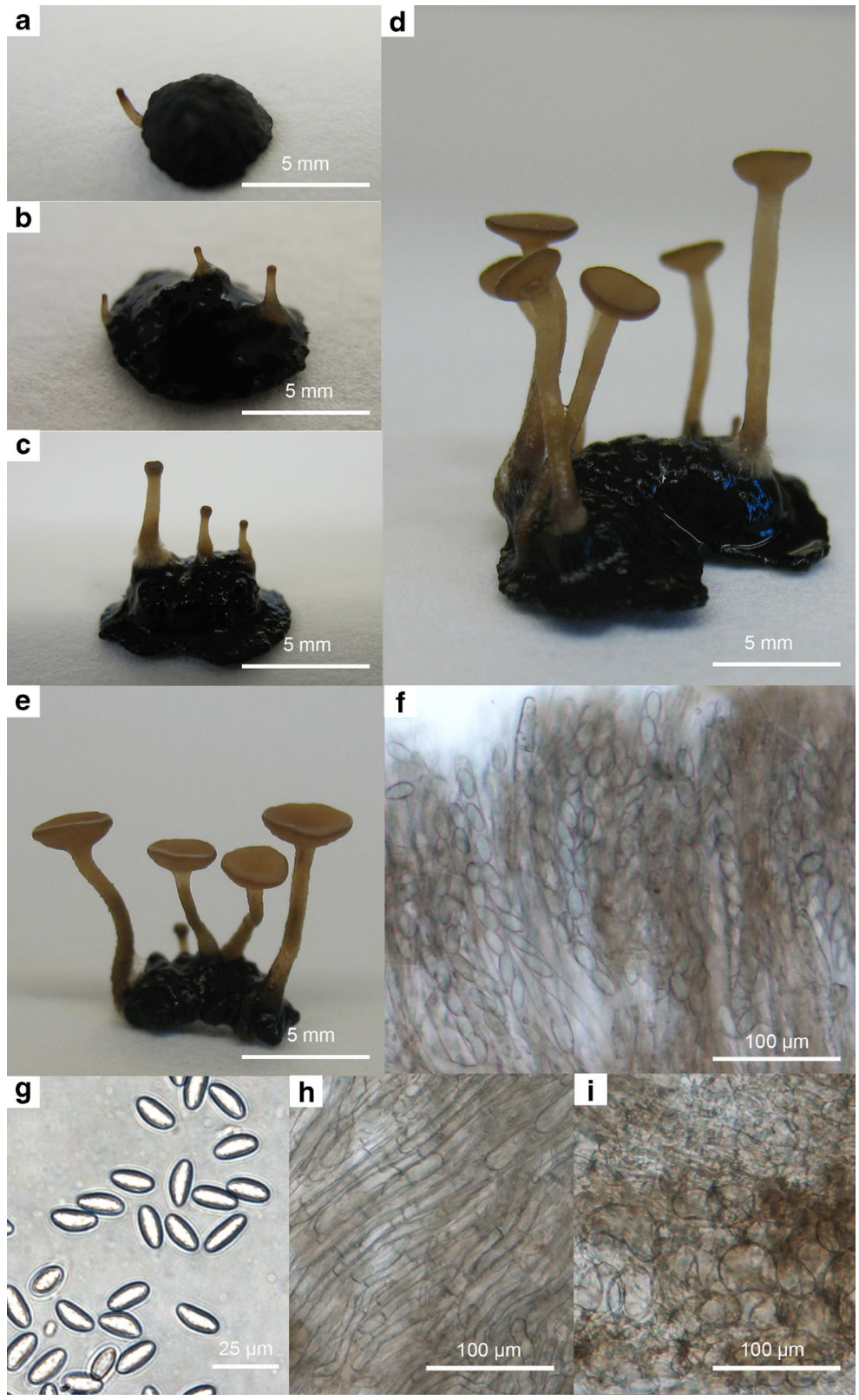


Fig. 3 Disease symptoms of B. elliptica on lily leaves, 36 hpi. a inoculation with ascospores, $\mathbf{b}$ inoculation with conidia

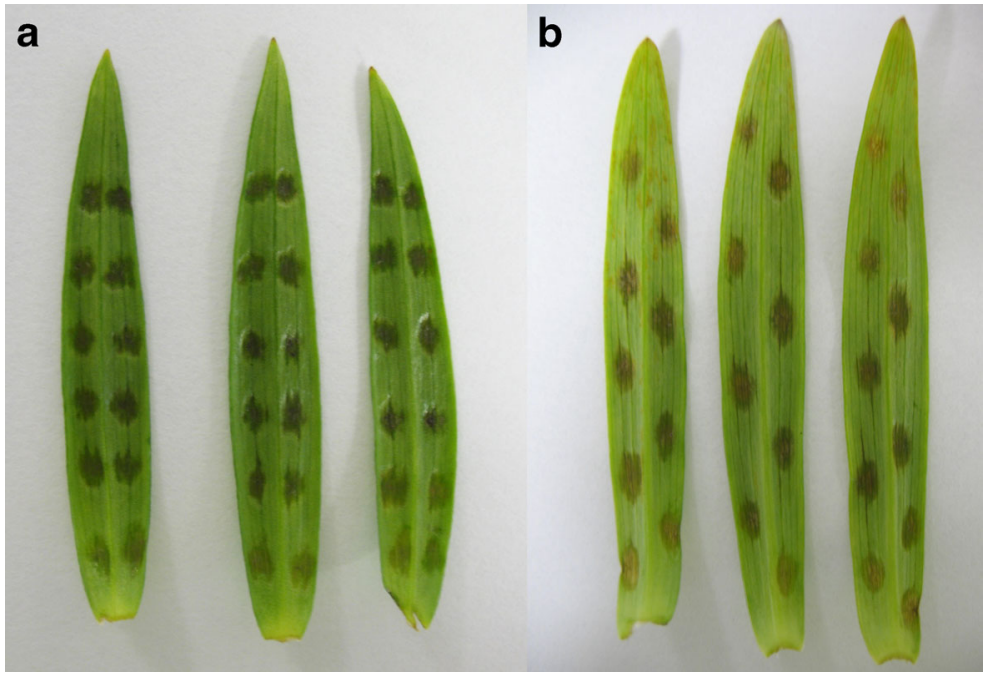

took significantly longer to develop than those of B. cinerea.

The MAT1-1-1 and MAT1-2-1 genes in B. elliptica are orthologous to the alpha-domain protein and the HMG-domain protein, respectively, which are conserved in all ascomycetes studied thus far. These two proteins jointly act as master regulators of the initiation of sexual fruiting body development, when expressed together in a dikaryotic cell (Pöggeler et al. 2006). The MAT1-1-5 and MAT1-2-4 genes in B. elliptica are orthologous to the MAT1-1-5 and MAT1-2-4 genes in $B$. cinerea and have no homologues outside the family Sclerotiniaceae (Amselem et al. 2011). Deletion of either the B. cinerea MAT1-1-5 gene or the MAT1-2-4 gene results in a defect in sexual reproduction, specifically in the developmental transition from stipe to apothecial disk (Terhem and van Kan, unpublished). Whether the B. elliptica MAT1-1-5 and MAT1-2-4 genes have a similar function in apothecial disk development remains to be established.

Alike in B. cinerea, the MAT alleles of B. elliptica both contain a truncated $M A T$ gene fragment derived from the opposite allele (i.e., a non-functional fragment of the MAT1-2-1 gene in the MAT1-1 locus and a nonfunctional fragment of the MAT1-1-1 gene in the MAT12 locus). The lengths and positions of the non-functional $M A T$ gene fragments are nearly identical between $B$. cinerea and B. elliptica (J. van Kan, unpublished observations). This configuration suggests that contemporary MAT loci of B. cinerea and B. elliptica have both evolved from an ancestral, homothallic locus, by two separate deletion events. Amselem et al. (2011) proposed an evolutionary scenario for the $B$. cinerea $M A T$ locus, in which deletion of the MAT1-1-5 gene as well as a large part of the MAT1-1-1 gene resulted in the emergence of a heterothallic MAT1-2 allele, whereas deletion of the MAT1-2-4 gene and the major part of the MAT1-21 gene yielded the heterothallic MAT1-1 allele. The configuration of the B. elliptica MAT alleles is in full agreement with the occurrence of such a scenario in a common ancestor of $B$. cinerea and B. elliptica.

The morphology of $B$. elliptica apothecia is in agreement with the general description of apothecia in the genus Botrytis (Whetzel 1945). The apothecia of B. elliptica range between 7 and $12 \mathrm{~mm}$ in height and the apothecial disks range from 3 to $4 \mathrm{~mm}$ in diameter and 0.5 to $1 \mathrm{~mm}$ in thickness. B. elliptica apothecia are similar in size to those of Botrytis ranunculi, but smaller than apothecia of $B$. cinerea, which can reach up to $25 \mathrm{~mm}$ in height (Bergquist and Lorbeer 1972; Faretra and Antonacci 1987). The ascospores of B. elliptica $(23 \times 10 \mu \mathrm{m})$ are substantially larger than those of B. cinerea $(13 \times 8 \mu \mathrm{m})$. The earliest primordia ruptured from the sclerotium in B. elliptica 74 days after fertilization; which is more than 7 weeks later than in B. cinerea (Faretra and Antonaci, 1987; Terhem and van Kan 2014). Whether the slow development of $B$. elliptica apothecia is due to conditions employed here, or is intrinsically slower than in $B$. cinerea remains unknown. B. elliptica apothecia are brown in colour and become darker when mature, alike typical characteristics of apothecia of the genus Botrytis (Whetzel 1945). 
When comparing $B$. elliptica apothecia with $B$. cinerea side by side, we noticed that $B$. elliptica apothecia in a young stage appear slightly more yellow-greyish as compared to the yellow-brown appearance of B.cinerea. The apothecia of B. elliptica are thicker and more deeply cup-shaped than those of $B$. cinerea. Furthermore, the stipes of $B$. elliptica are uniform in width, whereas stipes of $B$. cinerea are tapered to a narrow base (not shown).

Apothecia only developed in crosses with MAT1-2 strains acting as the maternal parent, but not in crosses of MAT1-1 strain Be9612 as the maternal parent, in spite of several attempts in multiple replicates. The reasons for the unsuccessful development of apothecia in the crosses with Be9612 as the maternal parent is unclear, but a similar feature was reported for certain $B$. cinerea strains (van der Vlugt-Bergmans et al. 1993). The observation that apothecia were never produced when sclerotia were incubated in sterile water indicates that the B. elliptica strains tested are not homothallic.

Individual ascospores collected from $B$. elliptica apothecia were analysed for the segregation of mating type alleles. The analysis of segregation showed that the MAT loci segregate nearly 1:1 in two independent experiments (Table 4). In a third experiment, a skewed segregation was observed, the reason of which remains unexplained. Nevertheless, in the total dataset, the segregation ratio did not significantly deviate from $1: 1$.

The four strains of $B$. elliptica used in these crosses were obtained from a field in which there was apparently a potential for sexual reproduction, as indicated by the presence of opposite mating types at the same location. Van den Ende and Pennock-Vos (1996) collected apothecia of B. elliptica on plant debris in the same fields as the strains used in this study, and they were the first to succeed in inducing production of apothecia of $B$. elliptica in vitro. They also tested the ascospores produced from apothecia by inoculating them on lily leaves. In the present study, inoculation of ascospores of $B$. elliptica on lily leaves caused similar symptoms as described by van den Ende and Pennock-Vos (1996). Disease development and lesion outgrowth was indistinguishable between inoculation with ascospores or conidia of $B$. elliptica. In view of the detection of $B$. elliptica apothecia in plant debris at the end of the winter (van den Ende and Pennock-Vos 1996), a high genetic diversity in the $B$. elliptica population that is indicative of extensive sexual reproduction (Staats et al. 2007) and our observation that ascospores are equally infectious as conidia, we propose that ascospores make an important contribution in the epidemiology of B.elliptica, by infecting young lily shoots emerging in early spring.

Acknowledgements The authors are grateful to Dr. Roger Shivas (Biosecurity Queensland, Brisbane, Australia) for feedback on the draft manuscript.

Funding This study was supported by the Ministry of Education Malaysia and Universiti Putra Malaysia.

Conflict of interest The authors declare that they have no conflict of interest.

Open Access This article is distributed under the terms of the Creative Commons Attribution License which permits any use, distribution, and reproduction in any medium, provided the original author(s) and the source are credited.

\section{References}

Amselem, J., Cuomo, C. A., van Kan, J. A. L., Viaud, M., Benito, E. P., Couloux, A., et al. (2011). Genomic analysis of the necrotrophic fungal pathogens Sclerotinia sclerotiorum and Botrytis cinerea. PLoS Genetics, 7, e1002230.

Bastiaansen, C., Koster, A. T. J., Van der Meer, L., van den Ende, J. E., Pennock, I., \& Buurman, F. (1997). A diseaseforecasting system of botrytis blight ('fire') in lily. Acta Horticulturae, 430, 657-660.

Beever, R. E., \& Parkes, S. L. (1993). Mating behaviour and genetics of fungicide resistance of Botrytis cinerea in New Zealand. New Zealand Journal of Crop and Horticultural Science, 21, 303-310.

Bergquist, R. R., \& Lorbeer, J. W. (1972). Apothecial production, compatibility and sex in Botryotinia squamosa. Mycologia, 64, 1270-1281.

Buchwald, N. (1953). Botryotinia (Sclerotinia) globosa sp. n. on Allium ursinum, the perfect stage of Botrytis globosa Raabe. Phytopathologische Zeitschrift, 20, 241-254.

Chastagner, G. A., \& Riley, K. (1990). Occurrence and control of benzimidazole and dicarboximide resistant Botrytis spp on bulb crops in Western Washington and Oregon. Acta Horticulturae, 266, 437-446.

Chastagner, G. A., Riley, K., \& Doss, R. P. (1992). An attempt to produce an apothecial state of Botrytis elliptica in vitro. Acta Horticulturae, 325, 689-694.

Chiou, A., \& Wu, W. (2001). Isolation, identification and evaluation of bacterial antagonists against Botrytis elliptica on lily. Journal of Phytopathology, 149, 319-324.

Doss, R. P., Christian, J. K., \& Chastagner, G. A. (1988). Infection of Easter lily leaves from conidia of Botrytis elliptica. Canadian Journal of Botany, 66, 1204-1208. 
Elliott, M. E. (1964). Self-fertility in Botryotinia porri. Canadian Journal of Botany, 42, 1393-1395.

Fang Hsieh, T., Wen Huang, J., \& Hsiang, T. (2001). Light and scanning electron microscopy studies on the infection of oriental lily leaves by Botrytis elliptica. European Journal of Plant Pathology, 107, 571-581.

Faretra, F., \& Antonacci, E. (1987). Production of apothecia of Botryotinia fuckeliana (de Bary) Whetz. under controlled environmental conditions. Phytopathologia Mediterranea, 26, 29-35.

Faretra, F., Antonacci, E., \& Pollastro, S. (1988). Sexual behaviour and mating system of Botryotinia fuckeliana, teleomorph of Botrytis cinerea. Journal of General Microbiology, 134, 2543-2550.

Fukumori, Y., Nakajima, M., \& Akutsu, K. (2004). Microconidia act the role as spermatia in the sexual reproduction of Botrytis cinerea. Journal of General Plant Pathology, 70, 256-260.

Furukawa, T., Ushiyama, K., \& Kishi, K. (2005). Botrytis blight of Taiwanese toad lily caused by Botrytis elliptica (Berkeley) Cooke. Journal of General Plant Pathology, 71, 95-97.

Groves, J. W., \& Loveland, C. A. (1953). The connection between Botryotinia fuckeliana and Botrytis cinerea. Mycologia, 45, 415-425.

Hennebert, G. L. (1973). Botrytis and Botrytis-like genera. Persoonia, 7, 183-204.

Huang, J., Hsieh, T. F., Chastagner, G. A., \& Hsiang, T. (2001). Clonal and sexual propagation in Botrytis elliptica. Mycological Research, 105, 833-842.

Hwang, B. K. (2001). Gray mold of day lily (Hemerocallis fulva L.) caused by Botrytis elliptica in Korea. The Plant Pathology Journal, 17, 305-307.

Kamenetsky, R., \& Okubo, H. (2012). Ornamental geophytes: from basic science to sustainable production. London: CRC Press.

MacRae, E. A. (1998). Lilies : a guide for growers and collectors. Portland: Timber Press.

Mansfield, J., \& Hutson, R. (1980). Microscopical studies on fungal development and host responses in broad bean and tulip leaves inoculated with five species of Botrytis. Physiological Plant Pathology, 17, 131-136.
Migheli, Q., Aloi, C., \& Gullino, M. (1990). Resistance of Botrytis elliptica to fungicides. Acta Horticulturae, 266, 429-436.

Pöggeler, S., Nowrousian, M., \& Kück, U. (2006). Fruiting-body development in ascomycetes. In U. Kües, R. Fischer, S. Pöggeler, M. Nowrousian, \& U. Kück (Eds.), Growth, Differentiation and sexuality (pp. 325-355). Berlin Heidelberg: Springer.

Shahin, A., van Kaauwen, M., Esselink, D., Bargsten, J., van Tuyl, J., Visser, R. G., et al. (2012). Generation and analysis of expressed sequence tags in the extreme large genomes Lilium and Tulipa. BMC Genomics, 13, 640.

Staats, M., van Baarlen, P., \& van Kan, J. A. L. (2007). AFLP analysis of genetic diversity in populations of Botrytis elliptica and Botrytis tulipae from the Netherlands. European Journal of Plant Pathology, 117, 219-235.

Terhem, R. B., \& van Kan, J. A. L. (2014). Functional analysis of hydrophobin genes in sexual development of Botrytis cinerea. Fungal Genetic and Biology, 71, 42-51.

van Baarlen, P., Staats, M., \& van Kan, J. A. L. (2004). Induction of programmed cell death in lily by the fungal pathogen Botrytis elliptica. Molecular Plant Pathology, 5, 559-574.

van den Ende, J., \& Pennock-Vos, M. (1996). Primary sources of inoculum of Botrytis elliptica in lily. Acta Horticulturae, 430, 591-596.

van der Vlugt-Bergmans, C. J. B., Brandwagt, B. F., van't Klooster, J. W., Wagemakers, C. A. M., \& van Kan, J. A. L. (1993). Genetic variation and segregation of DNA polymorphisms in Botrytis cinerea. Mycological Research, 97, 1193-1200.

Vleeshouwers, V. G. A. A., \& Oliver, R. P. (2014). Effectors as tools in disease resistance breeding against biotrophic, hemibiotrophic, and necrotrophic plant pathogens. Molecular Plant-Microbe Interactions, 27, 196-206.

Whetzel, H. H. (1945). A synopsis of the genera and species of the Sclerotiniaceae, a family of stromatic inoperculate Discomycetes. Mycologia, 37, 648-714.

Zerbino, D. R., \& Birney, E. (2008). Velvet: algorithms for de novo short read assembly using de Bruijn graphs. Genome Research, 18, 821-829. 